\title{
The impact of the COVID-19 pandemic on firms: a survey in Guangdong Province, China
}

\author{
Peng Zou, Di Huo and Meng Li id
}

\begin{abstract}
Background: The COVID-19 pandemic has affected all sectors of the world economy and society. To understand the impact of the pandemic on firms in China and suggest public policies to deal with the negative effects, we investigated firms in Guangdong Province.

Methods: The survey sample included 524 firms in 15 cities in Guangdong Province. We chose these firms from the list published by the government, considering the industrial characteristics of Guangdong province and firm size. The questionnaire was developed based on previous studies carried out by UNDP. It comprised four categories with a total of 17 questions. The executives of firms were contacted by telephone or WeChat, and were invited to answer self-administered questionnaires through an online survey platform. The data was analyzed by SPSS.

Results: The following key findings were revealed through the survey: (1) 48.7\% of firms maintained stability, and $35.1 \%$ experienced a halt in operation or faced closure; (2) Nearly 70-90\% already exploit online commerce or are willing to do so, and also remote office work, and digital operations. (3) $46 \%$ believe that they will certainly incur losses for 2020, and 83.5\% expect the city's GDP to decrease.

Conclusions: Firms in Guangdong Province have faced great challenges in the epidemic. Their production and operation activities have been limited, and they are facing significant risks. It is necessary to implement policies that would profoundly lower production costs for firms, help them survive this difficult period, and gradually return to normal business.
\end{abstract}

Keywords: COVID-19 pandemic, Economic impact, Public policy, Health risks

\section{Background}

The current COVID-19 is a rapidly evolving global challenge and like any pandemic, it weakens health systems, costs lives, and also poses great risks to the global economy and security [1-4]. According to data from World Health Organization (WHO) and Johns Hopkins University, as end- of June 2020, there have been ten million cases around the world, causing nearly 500,000 deaths in around 215 countries (https://www.arcgis.com/apps/opsdashboard/inde x.html). The COVID-19 pandemic is a public health

\footnotetext{
* Correspondence: rilanhio@hit.edu.cn

School of Management, Harbin Institute of Technology, No. 13 Fayuan District, Harbin 150001, China
}

emergency and is likely to continue to cause serious public health damage including major infectious diseases, mass unexplained diseases, major food poisoning and other serious public health issues [5]. Global economic growth is expected to decrease continually $[6,7]$ and according to the an OECD forecast, the global GDP growth rate will drop to $2.4 \%$ in 2020 [3]. The risk of uncertainty and global recession has increased greatly $[8,9],{ }^{1}$ due to disruptions in the supply chain, shrinking demand for consumption and investment, significant weakening of economic activities, and damaged market confidence. These factors are severely

\footnotetext{
${ }^{1}$ The International Monetary Fund (IMF) broadly defined the global economic growth rate to fall below $2.5 \%$ per year as a global recession.
}

(C) The Author(s). 2020 Open Access This article is licensed under a Creative Commons Attribution 4.0 International License, which permits use, sharing, adaptation, distribution and reproduction in any medium or format, as long as you give appropriate credit to the original author(s) and the source, provide a link to the Creative Commons licence, and indicate if changes were made. The images or other third party material in this article are included in the article's Creative Commons licence, unless indicated otherwise in a credit line to the material. If material is not included in the article's Creative Commons licence and your intended use is not permitted by statutory regulation or exceeds the permitted use, you will need to obtain permission directly from the copyright holder. To view a copy of this licence, visit http://creativecommons.org/licenses/by/4.0/. 
testing the resilience of many economies, the level of governance, and the effectiveness of international cooperation.

The impact of the epidemic on China's economy is significant [10-14]. In the first two months of 2020, China's added value in terms of size, investment, and consumption fell by $13.5,24.5$, and $20.5 \%$ year-on-year, and the unemployment rate reached $6.2 \%$, for the first quarter of 2020, China's GDP growth rate fell by $6.8 \%$, according to the data released by the National Bureau of Statistics of China on April 17 [15].

As the basic unit of the national economy, the operation of firms is key to the development of the national macro-economy. Therefore, it is necessary to understand the status of firms, their coping strategies, and the need for government policies to respond to the impact of the COVID-19 pandemic. Researchers have begun to analyze firms' marketing innovation strategies and strategic responses to the crisis during the pandemic [16-18]. In addition, some industries have also been analyzed in order to propose more targeted countermeasures for the pandemic [19]. However, the conclusions of these studies have not been empirically tested.

In this context, in order to explore the impact of the COVID-19 pandemic on firms in China and to suggest how public policies might be formulated to deal with the crisis, we investigated firms in Guangdong Province (the province with the highest GDP in China). The purpose of this research was to investigate 1) the impact of the pandemic on firms, 2) how they responded, and 3) and their expectations for the future. Some supporting policies are recommended.

\section{Methods}

\section{Study setting and design}

The research protocol was approved by the Institutional Review Committee of the School of Management, Harbin Institute of Technology, with approval number 2020-01. A survey was designed to be carried out in Guangdong Province.

The minimum sample size was calculated based on the formula below:

$$
\text { Sample Size }=z^{2} \sigma^{2} / E^{2}
$$

where $\mathrm{E}=0.05$ (margin of error); $\mathrm{z}=1.96$ (confidence level); and $\sigma=0.5$.

Based on the above parameters, the estimated minimum sample size was 384 . However, in order to improve the reliability of the data, the sample was increased to over 500 . The survey sample included 524 firms distributing in 15 cities including Guangzhou, Shenzhen, Dongguan, and Foshan (There are 21 cities in Guangdong Province and the GDP of the 15 cities included in our sample represent more than $90 \%$ of the total GDP of Guangdong Province). These firms were selected from a list of firms published by the government, considering the industrial characteristics of Guangdong province and the size of firms.

\section{Questionnaire development}

The questionnaire was developed based on previous studies carried out by United Nations Development Program (UNDP) in China [11]. It was piloted among 10 CEOs and firm owners. The questionnaire was further revised based on their feedback along with from two senior experts [20]. The final questionnaire included 17 questions distributed in four categories: demographic characteristics (3 questions); the impact of the pandemic on firms (6 questions); firms action (5 questions); and firm perceptions (3 questions) (Appendix 1).

\section{Data collection}

The survey was carried out from 10 April 2020 to 25 April 2020. Three researchers contacted the executives of firms via telephone or WeChat, and invited them to answer the self-administered questionnaires on "WJX", an online survey platform (https://www.wjx.cn/). Participation in the survey was fully voluntary and written consent was obtained from each participant. The objectives of the study, confidentiality of individual information, and other ethical considerations mentioned in the survey guidelines were explained to the participants prior to data collection. They were asked to answer as many of the questions as they could. However, if they were not sure about the answer, they could simply leave it blank. Altogether, 553 anonymous questionnaires were collected.

\section{Data processing and analysis}

The data was entered into Excel for data documentation. SPSS was applied to further analyze the data. A total of 29 participants were excluded from the sample because they answered less than 70\% questions, and missing some key answer s. Descriptive statistics of demographic characteristics of the sample and each item of questions were employed to summarize the data.

\section{Results}

\section{Demographic characteristics of the sample}

The effective response rate of the sample was $94.8 \%$ (524/553). The industries in the effective response investigation were Information technology (IT) (18\%), manufacturing (34.6\%), finance (12.4\%), real estate $(6.7 \%)$, and service and commercial industry (23.7\%). Other industries accounted for $4.8 \%$. This distribution is in line with the Guangdong's industrial characteristics. The size of the surveyed firms was relatively balanced. A total of 141 firms accounted for $26.9 \%$ of all the firms and have 50 
employees or fewer, 162 firms (30.1\%, 50-500 employees, 129 firms (24.4\%, 501-5000 employees), and 92 firms $17.6 \%, 5000$ employees or more). Table 1 shows the demographic characteristics of the firms by number and percentage, including industry, size, and location.
The impact of the pandemic on firms

Although half of the firms maintained their operations and overall stability, many experienced a halt in operations or faced closure for various reasons such as shortages of materials and stock (Q1 and Q2).

Table 1 Overview of the sample of firms

\begin{tabular}{|c|c|c|c|}
\hline & Field of business & Number of Firms & Percentage \\
\hline Industry & Sub-industry & & \\
\hline IT & / Software and hardware services / E-commerce / Internet operations & 94 & $17.94 \%$ \\
\hline \multirow[t]{13}{*}{ Manufacture } & Main Manufacture & 88 & $16.79 \%$ \\
\hline & Electronic technologies / Semiconductors / Integrated circuits & 14 & $2.67 \%$ \\
\hline & Clothing / Textiles / Leather & 7 & $1.34 \%$ \\
\hline & Aerospace / Aviation / Energy / Chemical & 10 & $1.91 \%$ \\
\hline & Machinery / Equipment / Heavy industry & 10 & $1.91 \%$ \\
\hline & Electric appliances & 5 & $0.95 \%$ \\
\hline & Furniture / Crafts / Toys & 6 & $1.15 \%$ \\
\hline & FMCG (food / beverage / cosmetics) & 12 & $2.29 \%$ \\
\hline & Automobiles and spare parts & 9 & $1.72 \%$ \\
\hline & Medical / Nursing / Health / Sanitation & 8 & $1.53 \%$ \\
\hline & Instrumentation / Industrial Automation & 5 & $0.95 \%$ \\
\hline & Pharmaceutical / Bioengineering / Medical Equipment & 15 & $2.86 \%$ \\
\hline & & 181 & $34.6 \%$ \\
\hline \multirow[t]{12}{*}{ Service and Commercial } & Publishing / Printing / Packaging & 5 & $0.95 \%$ \\
\hline & Advertising / PR / Media / Art & 4 & $0.76 \%$ \\
\hline & Law & 1 & $0.19 \%$ \\
\hline & Accounting / Auditing & 1 & $0.19 \%$ \\
\hline & Traffic / Transportation / Logistics & 11 & $2.10 \%$ \\
\hline & Education / Training / Scientific research / Colleges & 15 & $2.86 \%$ \\
\hline & Trading / Import \& Export & 13 & $2.48 \%$ \\
\hline & Wholesale / Retail & 13 & $2.48 \%$ \\
\hline & Communication / Telecommunications / Network equipment & 21 & $4.01 \%$ \\
\hline & Property Management / Commercial Centers & 8 & $1.53 \%$ \\
\hline & Agency / Consulting / Headhunting / Certification & 12 & $2.29 \%$ \\
\hline & & 124 & $23.7 \%$ \\
\hline Finance & Bank / Insurance / Securities / Investment Bank / Risk Fund & 65 & $12.40 \%$ \\
\hline Real estate and Architecture & Real estate development / Architectural engineering / Design & 35 & $6.68 \%$ \\
\hline \multirow[t]{10}{*}{ Other industry } & & 25 & $4.77 \%$ \\
\hline & Employees & & \\
\hline & 50 and below & 141 & $26.91 \%$ \\
\hline & $51-100$ & 54 & $10.31 \%$ \\
\hline & $101-300$ & 71 & $13.55 \%$ \\
\hline & $301-500$ & 37 & $7.06 \%$ \\
\hline & $501-1000$ & 42 & $8.02 \%$ \\
\hline & 1001-4999 & 87 & $16.60 \%$ \\
\hline & 5000 and above & 92 & $17.56 \%$ \\
\hline & Total & 524 & $100 \%$ \\
\hline
\end{tabular}


Firms are suffering from at least one of the following pressures: employees' salary and social insurance, rent, loss of orders, payment of accounts payable, and loan repayment (Q3). For firms with fewer than 50 employees, rent payments seem to be the key pact.

Most firms barely maintained production, facing a shortage of materials or lack of supply (Q4). A total of $22.9 \%$ of firms had orders from domestic customers cancelled, and $63.9 \%$ had overseas customers who cancelled orders or failed to send supplies on time.

Descriptive statistics can be found in Fig. 1.

\section{How firms responded to the crisis}

Firms recognized the problems and devoted more efforts to $R \& D$ and innovation. However, the epidemic has delayed the launch of new products as well as the progress of projects in cooperation with other institutions, especially for the IT industry (Q7). Many firms have faced higher labor costs, which have forced them to consider reducing the number of employees, cutting wages, and postponing recruitment until the effects of the pandemic are over (Q5, Q6 and Q8). Manufacturing has been facing a higher proportion of employment difficulties, and the real estate industry has been shedding the jobs. Both IT and Manufacturing industries have also sought out loans as well as funding from shareholders (Q8).

A high percentage of firms have already moved their operations to online or plan to do so (Q9). Likewise, many firms have already started working remotely and digital operations or plan to do so (Q10 and Q11).

Descriptive statistics can be found in Fig. 2 and Fig. 3.

\section{The expectations of firms}

A high percentage of firms believe that they will experience financial losses this year, while a lower percentage think they will be able to make a profit (Q13). However, firms with more than 1000 employees appear to be in a relatively good position to survive, and some believe that they will certainly make a profit and have sufficient cash flows.

More firms expected their local town to experience a decrease in GDP than those who thought that GDP will remain unchanged or even increase (Q14).

Most firms felt that the government needs reduce, exempt, or postpone social insurance, value added tax, income tax and other taxes (Q12). More than half of the firms expect that the government to stimulate consumption. They also need subsidies, for example, for rent, utilities, and post stabilization some firms expect to make a staged flexible salary. Smaller firms need more cash subsidies, while larger firms tend to get policies of extending loan repayment terms and debt forgiveness.

Descriptive statistics can be found Fig. 4 .

\section{Discussion}

Most of the research on public health emergencies has focused on changes in overall consumption trends, such as consumption behavior, changes in consumer decisionmaking and consumer psychology [21-24]. These studies show that pandemics reduce economic activity and employment, and inhibit consumption, which is in line with our findings on the impact of the COVID-19 pandemic. However, such studies only analyzed the trend in overall consumption, while we investigated the firms themselves, thereby more comprehensively reflecting the impact of the COVID-19 pandemic on economic activities.

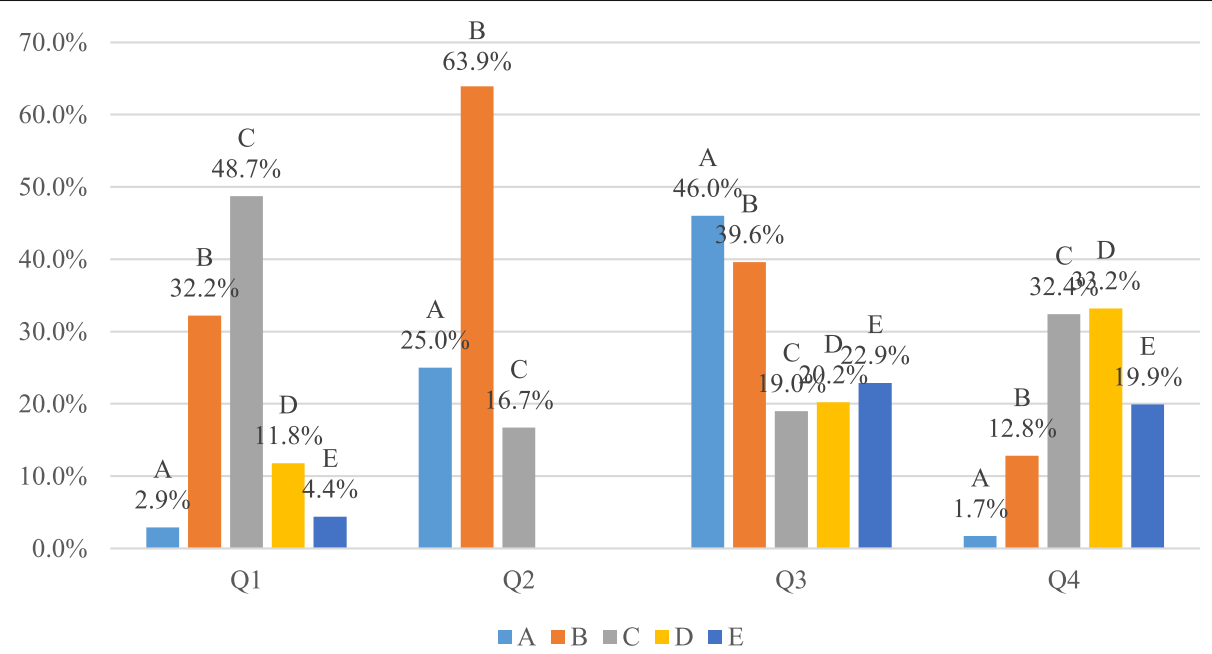

Fig. 1 Descriptive statistics of Q1--Q4. Note: Appendix 1 contains details of the questions and options 


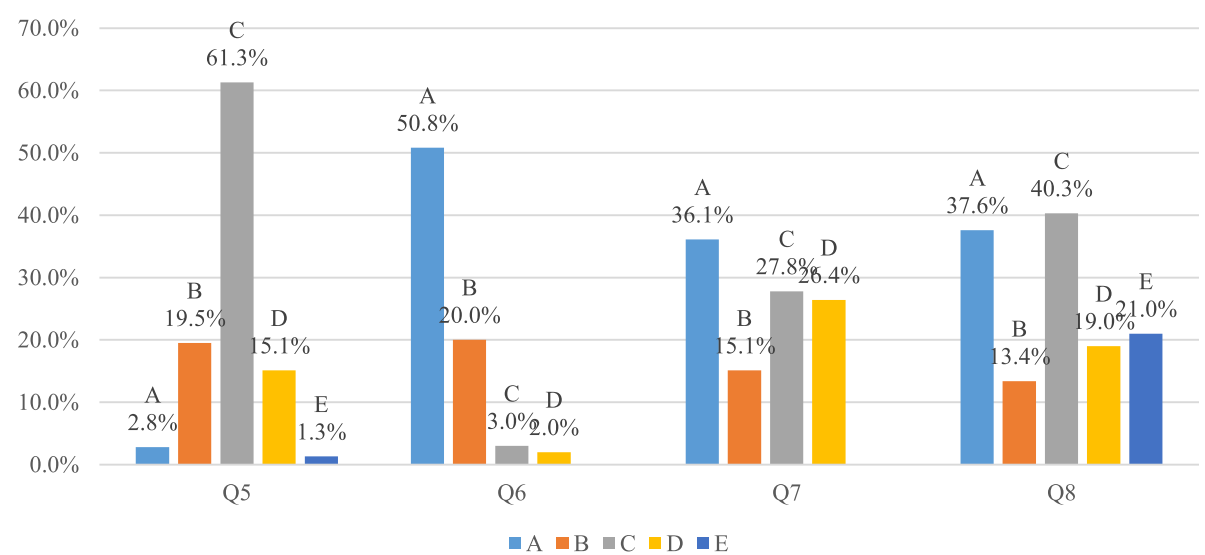

Fig. 2 Descriptive statistics of Q5-Q8. Note: Appendix 1 contains details of the questions and options

\section{The impact of the pandemic on firms}

Given the pandemic, returning to work was not the same as reaching production capacity. In fact, almost half of the firms were facing material shortages, some of them even said that they had run out of supplies (see answers to Q1 and Q2). In response to Q3 regarding operational pressures, our survey revealed that firms were facing employment and costs. In addition, $22.9 \%$ of firms had had orders cancelled from domestic customers. Many firms responded that the market expansion was also affected, due to the impossibility of site visiting and face-to-face meetings with customers.

Moreover, more than half of the firms reported a sharp increase in operating costs such as the cancellation of orders, delayed delivery, and production stagnation. Some of them had to deal with insolvency and compensation for breach of contract. Firms were also under the pressure of employees' salary, insurances, rent payments, settlement of accounts payable, and loan repayment.

As highlighted by the answers to Q4 (supply of raw materials, spare parts and other production and operation materials), the business owners in the interviews reported that supply chain links - the producing and processing of raw material parts, and logistics etc. were affected by the epidemic situation in various regions, with different degrees of delay in delivery and work stoppages while waiting for materials. The spread of epidemic to outside China affected many export businesses. Firms reported cancellation of orders or delayed receipt of goods from overseas customers.

How firms responded to the epidemic

According to the answers for Q5, Q6 and Q8, the epidemic also negatively impacted the technological

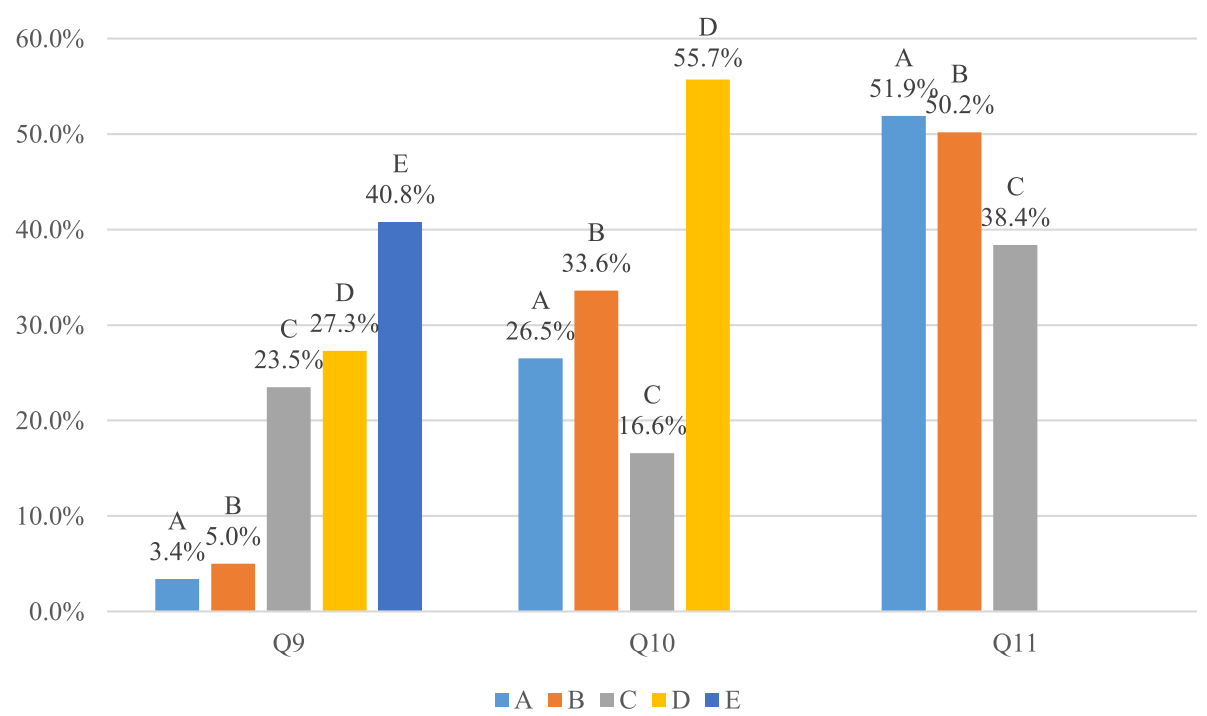

Fig. 3 Descriptive statistics of Q9-Q 11. Note: Appendix 1 contains details of the questions and options 


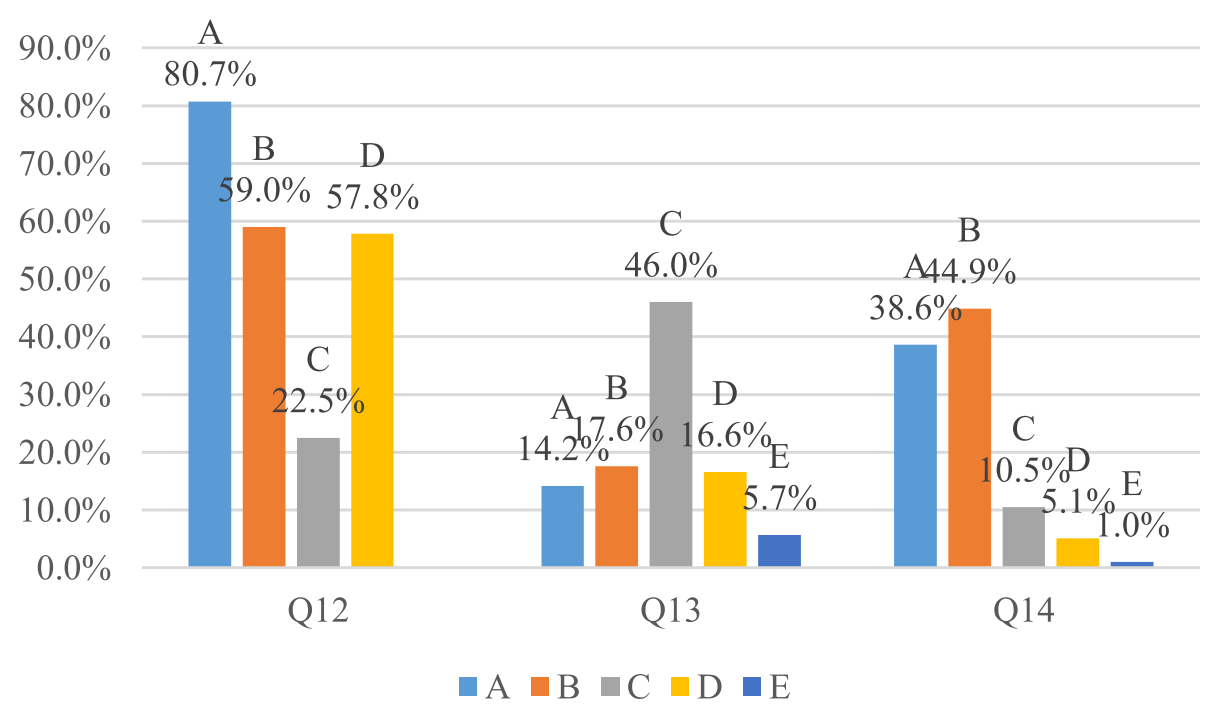

Fig. 4 Descriptive statistics of Q12--Q14

innovation and human resources in some firms. For example, the epidemic has delayed the launch of new products, new recruits, and the progress of projects in cooperation with other firms.

According to Q7, the combination of this pandemic and the impact of the Sino US trade dispute prompted some firms to recognize the problems and to devote more efforts to R \& D and innovation.

Q9 and Q10 indicate that, more than half of the firms believe that this pandemic has promoted the establishment of remote offices, remote recruitment, and remote business negotiation models, and the informatization and digitalization of firms have improved their ability to respond to major crises. A few firms also mentioned that the epidemic can eliminate competitors to a certain extent, by triggering the launch of new businesses, and accelerating changes in marketing approaches (such as community channel expansion). For example, the core business of clothing brand PeaceBird was offline retailing in large shopping malls. During the crisis, they transferred employees from offline stores to online sales teams. They successfully completed this channel transformation and survived the crisis by using livestreaming and social media platforms [25].

The epidemic has strengthened the determination of some firms to turn crises into opportunities and invest in new industries. At the same time, it has strengthened consumers' health awareness and changed their consumption behaviors [26-28]. Some firms reported that this trend has led to new business opportunities and has driven reforms in their marketing strategies. The interviewees indicated that there is a need to accelerate, for example, the development of online education, medical care, and 5G.
Some firms have changed the original store-based marketing mode and integrated channels for interactive marketing. For example, the store is not open, but the sales people conduct live broadcasts, group buying and social marketing, to name a few.

\section{The expectations of firms}

The result of this investigation indicate that rebound consumption will not come. Consumption is mainly determined by demand and the ability to pay [29]. The ability to pay depends on the consumer's current income and expectations of future income [30]. Since the epidemic has continued, almost half firms believe that there they will definitely incur losses this year.

Q13 asked "To what extent do you expect this pandemic will affect your firm's development in the first quarter of 2020?" and nearly half of firms predicted that losses will directly affect their employees' income and even work opportunities. More than 20\% of firms have reduced the number of staff to cope with the epidemic.

Moreover, respondents are also not optimistic about the GDP growth of the city where the firm is located (Q14). Among them, 83.5\% expected a decreasing trend in their city's GDP growth, and $38.6 \%$ predicted a significant decline. On the contrary, only a few respondents believed that GDP would remain unchanged or anticipated that GDP would increase. Therefore, there is insufficient support for any consumption rebound given expectations for reduced income and spending power.

Unfortunately, the Spring Festival, which took place at the height of this pandemic, would normally stimulate a high level of consumption [31] over a short period which is not protracted throughout the year [32]. In the long run, the epidemic will reduce people's willingness to 
consume apart from necessities and immediate needs. In the short term, consumer psychology has not fully returned to normal [33], and establishing a work mode that is compatible with epidemic prevention and control takes time. Therefore, the endogenous power of compensatory and rebound consumption is insufficient.

\section{Policy implications}

On the basis of our survey and considering the firms' appeal for government support, we believe that the following financial policies would stimulate consumption and help firms to survive.

(1) Financial policies supporting production and operation. Firms expect public policies and measures such as the "tax exemption, reduction, postponement, return and compensation", in order to substantially lower production costs for firms, and help firms survive the difficult period of production and operation, while gradually returning to normal business operations.

(2) Investment driving consumption. Investment should play a driving role in promoting consumption. Investment in fields such as public health facilities and health care should be increased to cultivate and expand consumer demand.

(3) Measures supporting and facilitating consumption. Holiday tourism products could be launched alongside a paid vacation system. Policies should be targeted to promote tourism and the 'night economy'.

(4) Role of industry organizations in promoting consumption. Industry organizations could release suppressed and frozen consumption by carrying out various activities such as shopping festivals and food festivals to stimulate consumption; and facilitate an environment for promoting online-tooffline integrated consumption, for example through preferential concessions, model innovation, policy stimulation, cooperation between banks and firms, strengthening services, and product innovation.

\section{Limitation of this study}

Our study has several limitations that provide opportunities for future research. First, this study can only be viewed as a preliminary study and more follow-up tracing investigations at different stages need to be conducted in order to monitor the continuing impact of the pandemic and the effectiveness of public policies and firms' responses. Second, this study focuses on China which was among the first countries to recover from the pandemic, more surveys should be implemented in other countries to explore how COVID-19 has impacted other cultural, social and governing systems. A cross-sector analysis is also needed in order to get more specific suggestions for different industries in different regions.

\section{Conclusions}

While many firms in Guangdong Province have maintained overall stability, others have experienced a halt in their operations or faced closure. Almost all the firms in our survey are willing to transform into online marketing, remote office work and digital operations. Half of the firms believe that there will be a certain loss this year, and a very high percentage of firms expected a decreasing trend in the city's GDP growth.

There is a need to fully understand the impact of the epidemic on consumption and the difficulty of promoting the recovery of consumption, also in terms of how industry has been affected by this pandemic. Policies need to be introduced to profoundly lower production costs for firms, and help firms survive this difficult period, and gradually return to normal business operations.

\section{Appendix}

Questionnaire

Survey on firms affected by the COVID-19 Pandemic

1. To what extent does has production and operations of your firm been affected by this pandemic? (single choice)

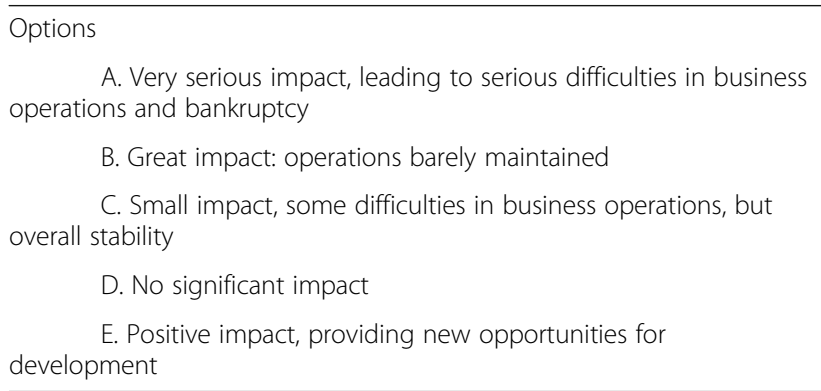

2. What are the reasons for the suspension of production and operations of your firm? (multiple choice, up to 2 items)

\footnotetext{
Options

A. Shortage of production materials.

B. Difficulty in developing market

C. Impact of measures taken to respond to the pandemic
} 
3. What are the main operating pressures that your firm is currently facing? (multiple choice, up to 3 items)

Options
A. Employee salaries, insurances
B. Rent (Buildings, Equipment)
C. Repayment of loans
D. Payment of accounts payable
E. Cancellation of orders

4. What is the current situation regarding the supply of raw materials, spare parts and other production and operation materials in your firm? (single choice)

\begin{tabular}{l}
\hline Options \\
A. Total disruption of supply \\
B. Supply shortage \\
C. Supply barely maintains production \\
D. Satisfactory supply \\
E. Normal supply
\end{tabular}

5. Does your company plan to reduce or increase the number of employees? (single choice)

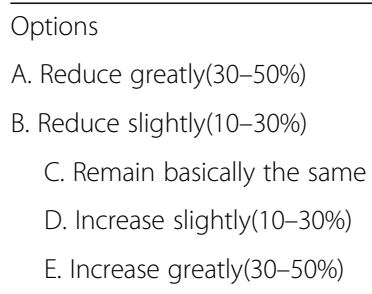

6. How has the pandemic affected recruitment? (multiple choice, up to 3 items)

Options
A. Increase in labor costs
B. Unable to find a suitable recruitment channel
C. Postponement or cancelation the existing recruitment plan

D Transition to online recruitment

7. What is the clearest impact of the pandemic on your firm's technological innovation? (multiple choice, up to 3 items)

\footnotetext{
Options

A R\&D process may affect the launching process of new product

B Unable to recruit suitable R\&D personnel

C. Unable to cooperate with other departments to carry out part of R \&

D work

D. Determined to invest more in technological innovation after being
}

\section{Questionnaire (Continued)}

better aware of the firm's self-development problems during the pandemic

8. How are you currently or planning to cope with the cash flow shortage? (multiple choice). WHAT IF THEY DON'T HAVE a CASH FLOW SHORTAGE?

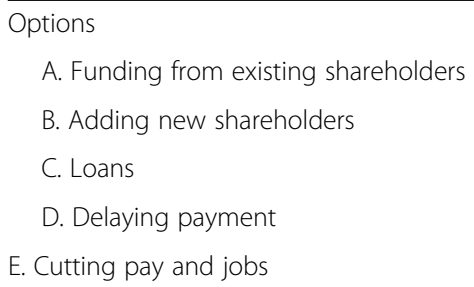

9. Are you willing to transform to online commerce?

Options

$$
\begin{aligned}
& \text { A. Very unwilling } \\
& \text { B. Unwilling } \\
& \text { C. Reasonably willing }
\end{aligned}
$$

D. Willing

E. Very willing

10. What self-help measures has your firm taken so far? (multiple choice)

Options

$$
\begin{aligned}
& \text { A. Applied for financing } \\
& \text { B. Increased online operations }
\end{aligned}
$$

C. Cut pay and jobs.

D. Implemented a remote office (digital office)

11. What are the potentially positive impacts of the pandemic in your view? (multiple choice, up to 3 items)

Options

$$
\begin{aligned}
& \text { A. Promote the establishment of remote office work } \\
& \text { B. Enhance information and digital construction of firms } \\
& \text { C. Help to better realize firm's shortcomings and solve existing }
\end{aligned}
$$


12. What policies do you expect the government will put in to place to help your firm overcome the difficulties? (multiple choice, up to 4 items)

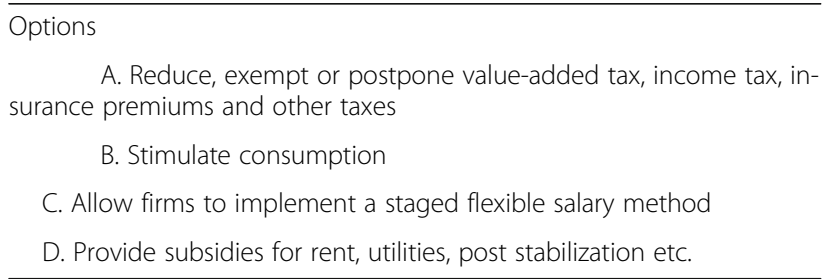

13. To what extent do you expect this pandemic will affect your firm's development in the first quarter of 2020?(single choice)

Options

A. Profits

B. Balance of income and expenditure

D. Losses

E. Serious losses

A. Bankruptcy

14. What has been the effect on your city's economic (GDP) growth in the first quarter of this year?

Options
A. Reduced significantly
B. Reduced slightly
C. Unchanged
D. Increased slightly
E. Increased significantly

15. Where is your firm located?

\begin{tabular}{l}
\hline Options \\
Chaozhou \\
Dongguan \\
Foshan \\
Guangzhou \\
Huizhou \\
Jiangmen \\
Maoming \\
Shantou \\
Shenzhen \\
Yangjiang \\
Zhanjiang \\
Zhongshan \\
Zhuhai
\end{tabular}

16. What industry does your firm belong to?

Options

IT / Software and hardware services / E-commerce / Internet operations

Catering / Entertainment / Tourism / Hotel

Publishing / Printing / Packaging

Electronic technology / Semiconductor / Integrated circuit

Law

Real estate development / Architectural engineering / Design

Clothing / Textile / Leather

Advertising / PR / Media / Art

Aerospace / Aviation / Energy / Chemical

Accounting / Auditing

Machinery / equipment / Heavy industry

Home appliance industry

Furniture / Crafts / Toys

Traffic / Transportation / Logistics

Education / Training / Scientific research / College

FMCG (food / beverage / cosmetics)

Trading / Import \& Export

Agriculture / Fishery / Forestry

Wholesale / Retail

Automobile and spare parts

Communication / Telecommunications operations / Network equipment Property Management / Commercial Center

Medical / Nursing / Health / Sanitation

Instrumentation / Industrial Automation

Bank / Insurance / Securities / Investment Bank / Risk Fund

Pharmaceutical / Bioengineering / Medical Equipment

Manufacture

Consulting / Headhunting / Certification

Others

17. How many employees are there in your company?
Options
50 and below
$51-100$
$101-300$
$301-500$
$501-1000$
1001-4999
5000 and above

\section{Abbreviations}

COVID-19: Coronavirus disease 2019; OECD: Organization for Economic Cooperation and Development; GDP: Gross Domestic Product; WHO: World Health Organization; IMF: World Health Organization; CEO: Chief Executive 
Officer; SPSS: Statistical Product and Service Solutions; R\&D: Research and Development; UNDP: United Nations Development Program

\section{Acknowledgements}

We would like to thank Dr. Hao Li and the anonymous reviewers for their valuable comments in improving the quality of this article.

\section{Authors' contributions}

PZ conceived of the study and drafted the manuscript. DH performed the statistical analysis and helped to draft the manuscript. ML conceived of the study and participated in its design and coordination. The authors read and approved the final manuscript.

\section{Funding}

This research is partially funded by a research grant from the National Natural Science Foundation of China (CN) under project No. 71972060 and 71672047

\section{Availability of data and materials}

Please contact the corresponding author for data requests.

\section{Ethics approval and consent to participate}

The research protocol was approved by the Institutional Review Committee School of Management, Harbin Institute of Technology, with the approval number 2020-01.

\section{Consent for publication}

Not applicable.

\section{Competing interests}

The authors declare that they have no competing interests.

Received: 21 May 2020 Accepted: 7 July 2020

Published online: 02 September 2020

\section{References}

1. Chattu KV, Adisesh A, Yaya S. Canada's role in strengthening global health security during the COVID-19 pandemic. Global Health Res Policy. 2020;5: $16-8$.

2. WHO. Health Security. Available at: https://www.who.int/health-security/en/. Accessed 24 Mar 2020

3. Orlik T, Rush J, Cousin M, Hong J. Coronavirus could cost the global economy \$2.7 trillion. Here's how. 2020. Available at: https://www. bloomberg.com/graphics/2020-coronavirus-pandemic-global-economic-risk/. Accessed 13 Mar 2020

4. Paul E, Brown G, Ridde V. COVID-19: time for paradigm shift in the nexus between local, national and global health. BMJ Glob Health. 2020;5(4):1-5.

5. The State Council of PRC. Regulations on emergency response to public health emergencies: Beijing, China Fangzheng Press; 2003.

6. van Wees SH, Holmer H. Global health beyond geographical boundaries: reflections from global health education. BMJ Glob Health. 2020:5(5):3.

7. Nagesh S, Chakraborty S. Saving the frontline health workforce amidst the COVID-19 crisis: challenges and recommendations. J Glob Health. 2020;10(1): 345.

8. Liu P, Guo Y, Qian X, Tang S, Li Z, Chen L. China's distinctive engagement in global health. Lancet. 2014;384(9945):793-804.

9. Zhang M, Kim R. Occupational health and safety in China: from emergency response to Jiangsu chemical explosion to long-term governance improvement. J Glob Health. 2020:10:7-15.

10. Kim H. The sociopolitical context of the COVID-19 response in South Korea. BMJ Glob Health. 2020;5(5):8.

11. United Nations Development Program in China Assessment report on impact of covid19 pandemic on Chinese enterprises. Available at: https:// www.cn.undp.org/content/china/zh/home/library/crisis_prevention_and_ recovery/assessment-report-on-impact-of-covid-19-pandemic-onchineseente.html. Accessed 7 Apr 2020

12. Tuangratananon $\mathrm{T}$, Tang $\mathrm{K}$, et al. China: leapfrogging to become a leader in global health. J Glob Health. 2019:9:010312.

13. Knight JB. China as a developmental state. World Econ. 2014;37(10):1335-47.
14. Wang X, Sun T. China's engagement in global health governance: a critica analysis of China's assistance to the health sector of Africa. J Glob Health. 2014;4(1):793-804.

15. National bureau of statistics of china. Available at: http://www.stats.gov.cn/. Accessed 17 April 2020

16. Wang Y, Hong A, Li X, Gao J. Marketing innovations during a global crisis: a study of China firms' response to COVID-19. J Bus Res. 2020;116:214-20.

17. Wenzel M, Stanske S, Lieberman MB. Strategic responses to crisis. Strateg Manag J. 2020;41:7-18.

18. He H, Harris $L$. The impact of Covid-19 pandemic on corporate social responsibility and marketing philosophy. J Bus Res. 2020;116:176-82.

19. Pantanoa E, Pizzib G, Scarpib D, Dennisc C. Competing during a pandemic? Retailers' ups and downs during the COVID-19 outbreak. J Bus Res. 2020; 116:209-13.

20. Shah P, Shrestha R, Mao Z, et al. Knowledge, attitude, and practice associated with antibiotic use among university students: a survey in Nepal. Int J Environ Res Public Health. 2019:16(20):1-11.

21. Ordaz-Németh I, Arandjelovic M, Boesch L, et al. The socio-economic drivers of bushmeat consumption during the west African Ebola crisis. PLoS Negl Trop Dis. 2017;11(3):1-22.

22. Bowles J, Hjort J, Melvin T, et al. Ebola, jobs and economic activity in Liberia. J Epidemiol Community Health. 2016;70(3):271-7.

23. Mizrachi I, Fuchs G. Should we cancel? An examination of risk handling in travel social media before visiting bola-free destinations. J Hosp Tour Manag. 2016;28:59-65.

24. Peng EY-C, Lee M-B, Tsai S-T, et al. Population-based post-crisis psychological distress: an example from the SARS outbreak in Taiwan. J Formos Med Assoc. 2010;109(7):524-32.

25. ChinaSSPP.com. The average daily retail sales of domestic clothing brand Peacebird exceeded 8 million during COVID-19 crisis. Available at http:// www.chinasspp.com/News/Detail/2020-2-11/446723.htm. Accessed 28 Apr 2020

26. Li JB, Yang A, Dou K. Chinese public's knowledge, perceived severity, and perceived controllability of the COVID-19 and their associations with emotional and behavioral reactions, social participation, and precautionary behavior: A national survey. PsyArXiv Preprints. 2020.

27. Xiang Y-T, Yang Y, Li W. Timely mental health care for the 2019 novel coronavirus outbreak is urgently needed. Lancet Psychiatry. 2020;7(3):228-9.

28. Zhang J, Wu W, Zhao X. Recommended psychological crisis intervention response to the 2019 novel coronavirus pneumonia outbreak in China: a model of West China hospital. Precision Clin Med. 2020;1:1-12.

29. Yan L, Liu MT, Chen X. An arousal-based explanation of affect dynamics. Eur J Mark. 2016;50(7-8):1159-84.

30. Di Muro F, Murray KB. An arousal regulation explanation of mood effects on consumer choice. J Consum Res. 2012;39(3):574-84.

31. Chen X, Li F, Nydegger L. Brief sensation seeking scale for Chinese - cultura adaptation and psychometric assessment. Personal Individ Differ. 2013;54(5): 604-9.

32. Jia J, Lu X, Yuan Y, et al. Population flow drives spatio-temporal distribution of COVID-19 in China. Nature. 2020;582(7812):1-11.

33. Zhang L, Zhang C, Shang L. Sensation-seeking and domain-specific risktaking behavior among adolescents: risk perceptions and expected benefits as mediators. Personal Individ Differ. 2016:101:299-305.

Ready to submit your research? Choose BMC and benefit from:

- fast, convenient online submission

- thorough peer review by experienced researchers in your field

- rapid publication on acceptance

- support for research data, including large and complex data types

- gold Open Access which fosters wider collaboration and increased citations

- maximum visibility for your research: over $100 \mathrm{M}$ website views per year

At BMC, research is always in progress.

Learn more biomedcentral.com/submissions 